\title{
Citizen Science in Human Medicine and the Use of Software-Systems: A Rapid Scoping Review
}

\author{
Jannik SCHAAF ${ }^{\mathrm{a}, 1}$, Michaela NEFF ${ }^{\mathrm{a}}$, Joerg SCHEIDT ${ }^{\mathrm{b}}$, Michael STEGLICH ${ }^{\mathrm{b}}$, \\ and Holger STORF ${ }^{\mathrm{a}}$ \\ ${ }^{a}$ Medical Informatics Group, University Hospital Frankfurt, \\ Frankfurt, Germany \\ ${ }^{\mathrm{b}}$ Institute of Information Systems, University of Applied Sciences Hof, \\ Hof, Germany
}

\begin{abstract}
Citizen science allows involving interested citizen in the entire research process in science. In the past, various citizen science projects have been performed in different research fields, especially in human medicine. We conducted a rapid scoping review to determine which citizen projects in human medicine already used software-based systems to engage citizens in the research process. Furthermore, we analysed which of the software-systems are publicly available, especially in the field of rare diseases, how citizens can participate using those tools and whether the usability was rated by the participants. To get insights for our project "SelEe (Seltene Erkrankungen bürgerwissenschaftlich erforschen)", which is a citizen science project in rare diseases funded by the Federal Ministry of Education and Research (BMBF), we aimed to identify projects in this research area. We searched PubMed for articles between 2011 and 2021 and performed a title- and abstract screening, as well as a full-text screening. Finally, 12 studies were identified in different research areas like public health, genetic research and infectious diseases. We could not identify any study directly associated with rare diseases. None of the studies investigated usability of those systems. Furthermore, five publicly available citizen science software-systems were identified. Three of them are general systems that allow creating, operating, managing citizen science projects and including citizens in the research process. In further investigations, we will check and compare these systems, if they are appropriate for use in our SelEe-project.
\end{abstract}

Keywords. Citizen Science, Scoping Review, Rare Diseases

\section{Introduction}

"Citizen science" projects allow citizens without any knowledge in sciences or the scientific process to participate in scientific projects by formulating research questions, performing observations and measurements, as well as evaluating and publishing data [1]. In the last 20 years, citizen science has developed as an instrument that makes it possible to involve citizens in improving scientific knowledge and goals. The use of

${ }^{1}$ Corresponding Author, Jannik Schaaf, Medical Informatics Group, University Hospital Frankfurt, Theodor-Stern-Kai 7, 60590 Frankfurt am Main, Germany; E-mail: jannik.schaaf@kgu.de 
citizen science is becoming increasingly popular and is not limited to any scientific field [2]. Therefore, various examples of applications in human medicine are also available, e.g. in the research of COVID-19 [3, 4, 5]. The growth of citizen science projects is also supported by the increasing use of websites or mobile applications that allow citizens to collectively contribute, analyse or publish results [6].

In Germany, the Federal Ministry of Education and Research (BMBF) is funding 15 different citizen science projects, starting in 2021. In this initiative, four projects are being funded in the field of human medicine [4]. One of these projects is "SelEe: Seltene Erkrankungen bürgerwissenschaftlich erforschen" (www.selee.de), with the aim of including citizens in the research of rare diseases (RDs). Since only a small part of the population is affected by RDs and knowledge about these diseases is often low, citizen science projects are one possibility to improve research knowledge in this area $[8,9]$. Within the SelEe-project, citizens from Germany will be involved in the entire research process. They can actively shape the selection of RDs that should be studied in the project and formulate research objectives. All data and information in the project will be collected and made available via an online-based platform called "SelEe citizen science platform", in which citizens can participate.

Despite the overall increasing number of software-based systems like webapplications and mobile-apps [10], we are not aware of any reviews about developments and current systems used in the context of citizen science in human medicine. Therefore, the objectives of this study were to perform a rapid scoping review to give interested researchers in citizen science an overview of (1) which studies are available using software-based systems in human medicine citizen science projects and if were in the field of rare diseases. Furthermore, we investigated (2) which systems are available (e.g. as open-source software) and (3) how citizens can participate using those tools. Furthermore (4) it was of interest whether the usability of those systems were rated by the citizens.

\section{Methods}

The reporting of this scoping review complies with PRISMA-ScR (Preferred Reporting Items for Systematic Reviews and Meta-Analyses extension for Scoping Reviews). We considered 19 out of 22 PRISMA-ScR items. Two items were optional, another item, which is about study-registration, was not considered, since the study was not registered online [11]. We searched PubMed for peer-reviewed articles from March 07, 2011 through March 07, 2021. Keywords for the search were derived through an initial search and authors' experience. The result was a set of keywords including "citizen science", "software" and "rare diseases", using MeSH-terms (Medical Subject Headings) and nonMeSH terms. This results in a final search query, shown in Table 1.

Table 1. Final query of the entire search

(Citizen Science[MeSH Terms] AND Software [MeSH Terms])

OR (Citizen Science[MeSH Terms] AND Rare Diseases [MeSH Terms])

OR ((Citizen Science) AND Software)

OR ((Citizen Science) AND rare diseases)

In accordance to PRISMA-ScR, we performed two screening rounds to select publications: a screening based on bibliographic data and a full-text screening. In the first screening round, publications were included if they contained a peer-reviewed 
article and/or conference proceedings written in English with an available abstract. Publications were only included if a citizen science project in human medicine was described where citizens could interact and participate in the project. Articles about other sciences, e.g. ecology or animal biology, were excluded. The full-text publications were screened where accessible, if the articles described the use of software-systems in the citizen science project. In both screening rounds, the screening was performed by one and compared by another author. To analyse and present the results (called data charting in scoping reviews), we defined the following data items and linked them to our research questions: "study/aim (1)", "research area" (1), rare diseases (1), "software availability (2)", "software type (2)", "citizen participation (3)" and "usability checked (4)"

\section{Results}

The search identified 85 articles in PubMed (shown in Figure 1). As there were no duplicates, the 85 were used for title and abstract screening. In this context, 60 articles were excluded and 25 were considered as further relevant. This number was further reduced because full text was not accessible for 5 articles. After assessing the eligibility of the remaining 20 articles, 8 articles were excluded because they did not describe a software-system in the context of citizen science in human medicine. Therefore, 12 articles were identified for further analysis, as shown in Table 2.

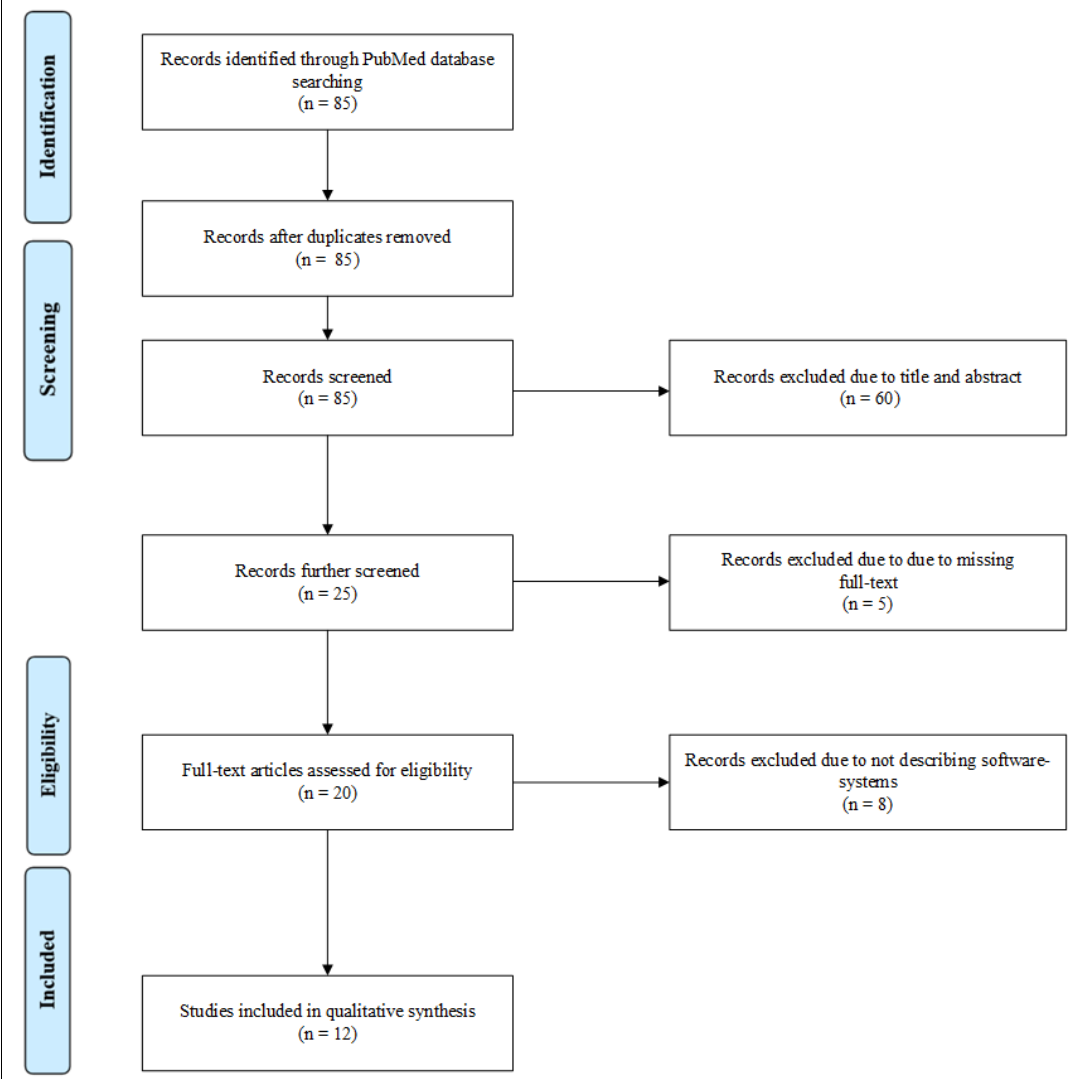

Figure 1. PRISMA-ScR flow diagram 
Table 2. Results of the qualitative synthesis

\begin{tabular}{|c|c|c|c|c|}
\hline Study/Aim & $\begin{array}{l}\text { Research } \\
\text { area }\end{array}$ & Citizen participation & $\begin{array}{l}\text { Usability } \\
\text { checked }\end{array}$ & $\begin{array}{l}\text { Software } \\
\text { type }\end{array}$ \\
\hline $\begin{array}{l}\text { [3] Caputo et al.: } \\
\text { Monitor } \\
\text { perception } \\
\text { mosquito } \\
\text { abundance and } \\
\text { nuisance in Italy } \\
\text { and beyond }\end{array}$ & $\begin{array}{l}\text { Public } \\
\text { Health }\end{array}$ & $\begin{array}{l}\text { ZanaMapp, a mobile app that } \\
\text { allows users to answer questions } \\
\text { about mosquito presence, } \\
\text { abundance and nuisance, as well } \\
\text { as geolocalization. }\end{array}$ & No & $\begin{array}{l}\text { Mobile } \\
\text { Application }\end{array}$ \\
\hline $\begin{array}{l}\text { [4] Ulahannan et } \\
\text { al.: Open data } \\
\text { visualization of } \\
\text { COVID-19 } \\
\text { outbreak } \\
\text { Kerala, India } \\
\end{array}$ & $\begin{array}{l}\text { Infectious } \\
\text { diseases }\end{array}$ & $\begin{array}{l}\text { Citizen-provided, visualized, } \\
\text { distributed and interpreted data on } \\
\text { a COVID-19 web-platform: } \\
\text { https://team.covid19kerala.info/ }\end{array}$ & No & $\begin{array}{l}\text { Web- } \\
\text { Application }\end{array}$ \\
\hline $\begin{array}{l}\text { [12] Hartshorne et } \\
\text { al.: Pushkin, an } \\
\text { open-source } \\
\text { platform for } \\
\text { designing and } \\
\text { conducting citizen } \\
\text { social sciences } \\
\text { projects }\end{array}$ & $\begin{array}{l}\text { Citizen } \\
\text { science } \\
\text { software }\end{array}$ & $\begin{array}{l}\text { Sharing experiments data, provide } \\
\text { personal feedback and discuss in } \\
\text { forums. Own script language for } \\
\text { behavioural experiments. }\end{array}$ & No & $\begin{array}{l}\text { Web } \\
\text { Application }\end{array}$ \\
\hline $\begin{array}{l}\text { [13] Vicens et al.: } \\
\text { Platform to assist } \\
\text { the deployment of } \\
\text { human } \\
\text { behavioural } \\
\text { experiments }\end{array}$ & $\begin{array}{l}\text { Citizen } \\
\text { science } \\
\text { software }\end{array}$ & $\begin{array}{l}\text { Collect decision of participants } \\
\text { while interacting with virtual real- } \\
\text { life situations in a computer-game. }\end{array}$ & No & $\begin{array}{l}\text { Web } \\
\text { Application }\end{array}$ \\
\hline $\begin{array}{l}\text { [14] Wang et al.: } \\
\text { Provision of a } \\
\text { citizen science } \\
\text { platform, where } \\
\text { projects can be } \\
\text { started } \\
\text { managed and }\end{array}$ & $\begin{array}{l}\text { Citizen } \\
\text { science } \\
\text { software }\end{array}$ & $\begin{array}{l}\text { The entry of citizen-based data is } \\
\text { supported by a meta-data model } \\
\text { approach to standardize the data } \\
\text { described. }\end{array}$ & No & $\begin{array}{l}\text { Web } \\
\text { Application }\end{array}$ \\
\hline $\begin{array}{l}\text { [15] Klepac et al.: } \\
\text { citizen science } \\
\text { experiment in UK } \\
\text { to study outbreaks } \\
\text { of pandemics }\end{array}$ & $\begin{array}{l}\text { Infectious } \\
\text { diseases }\end{array}$ & $\begin{array}{l}\text { Use of a smartphone app, which } \\
\text { records volunteers' movements } \\
\text { and allows submitting self- } \\
\text { reported contacts. }\end{array}$ & No & $\begin{array}{l}\text { Mobile } \\
\text { Application }\end{array}$ \\
\hline $\begin{array}{l}\text { [16] Candido Dos } \\
\text { Reis et al.: Cell } \\
\text { Slider is a project, } \\
\text { where citizens can } \\
\text { score tumors } \\
\text { based on images } \\
\text { of breast cancer }\end{array}$ & Oncology & $\begin{array}{l}\text { Access to a web-platform } \\
\text { (http://www.cellslider.net/), } \\
\text { training of scoring tumors, scoring } \\
\text { of images based on closed } \\
\text { questionnaires. }\end{array}$ & No & $\begin{array}{l}\text { Web } \\
\text { Application }\end{array}$ \\
\hline $\begin{array}{l}\text { [17] Meakin et al:: } \\
\text { Segmentation of } \\
\text { anatomy from } \\
\text { medical images } \\
\text { through citizen }\end{array}$ & Anatomy & $\begin{array}{l}\text { Citizens were recruited via social } \\
\text { media. They used an image dataset } \\
\text { and segmentation data which } \\
\text { includes images of magnetic } \\
\text { resonance imaging. }\end{array}$ & No & $\begin{array}{l}\text { Desktop } \\
\text { Software }\end{array}$ \\
\hline $\begin{array}{l}\text { [18] McGehee et } \\
\text { al.: Protein folding } \\
\text { via a visual } \\
\text { simulator used by } \\
\text { citizen }\end{array}$ & $\begin{array}{l}\text { Genetic } \\
\text { research }\end{array}$ & $\begin{array}{l}\text { Citizens can use the software } \\
\text { Polyfold to visually simulate the } \\
\text { distance-based protein folding } \\
\text { process without any knowledge in } \\
\text { protein biochemistry }\end{array}$ & No & $\begin{array}{l}\text { Desktop } \\
\text { Software }\end{array}$ \\
\hline
\end{tabular}




\begin{tabular}{|c|c|c|c|c|}
\hline Study/Aim & $\begin{array}{l}\text { Research } \\
\text { area }\end{array}$ & Citizen participation & $\begin{array}{l}\text { Usability } \\
\text { checked }\end{array}$ & $\begin{array}{l}\text { Software } \\
\text { type }\end{array}$ \\
\hline $\begin{array}{l}\text { [19] Kawrykow et } \\
\text { al.: To improve } \\
\text { multiple sequence } \\
\text { alignment through } \\
\text { citizen scientists }\end{array}$ & $\begin{array}{l}\text { Genetic } \\
\text { research }\end{array}$ & $\begin{array}{l}\text { Phylo is a web-based game that } \\
\text { allows citizen scientists to support } \\
\text { the multiple sequence alignments } \\
\text { in the research of genetic diseases. }\end{array}$ & No & $\begin{array}{l}\text { Web } \\
\text { Application }\end{array}$ \\
\hline $\begin{array}{l}\text { [20] Tuckett et al.: } \\
\text { Increase physical } \\
\text { activity in older } \\
\text { adults }\end{array}$ & Public health & $\begin{array}{l}\text { Citizens used a mobile web app } \\
\text { with the goal to geocode photos } \\
\text { and to create audio narratives of } \\
\text { their physical environment (e.g. } \\
\text { parks, playgrounds or crosswalks). } \\
\text { Citizens use the results to advocate } \\
\text { for improvements regarding } \\
\text { physical activity in their } \\
\text { community. }\end{array}$ & No & $\begin{array}{l}\text { Mobile } \\
\text { Application }\end{array}$ \\
\hline $\begin{array}{l}\text { [21] Sheats et al.: } \\
\text { Motivate residents } \\
\text { to use a mobile } \\
\text { app to assess and } \\
\text { advocate for } \\
\text { healthy food } \\
\text { environments }\end{array}$ & Public health & $\begin{array}{l}\text { Usage of a mobile app to collect } \\
\text { data (geocoded photos, audio } \\
\text { narratives) about aspects of their } \\
\text { environment that promote or } \\
\text { inhibit healthy nutrition. Citizens } \\
\text { use the results to advocate for } \\
\text { improvements regarding healthy } \\
\text { food in their community. }\end{array}$ & No & $\begin{array}{l}\text { Mobile } \\
\text { Application }\end{array}$ \\
\hline
\end{tabular}

\section{Discussion}

Our scoping review is the first to summarize the evidence of citizen science projects in human medicine, where citizens can participate in the projects by using software-based systems. Regarding to research question (1), we identified 12 relevant studies between 2011 and 2021. The results show that the studies are from different research areas. However, several studies are available in the field of public health, genetic research and infectious diseases $[3,4,14,18-21]$. There were no studies available in the field of RD's.

We identified "citizen science software" that are available for usage in citizen science projects (research question 2), for example to administer projects or to involve citizens [12-14]. These tools allow researchers of citizen science projects to create and operate platforms for their project at an early stage. While the systems of Hartsthorne et al. [12] and Vicens et al. [13] are open-source and thus individually expandable, Wang et al. [14] only provides an online platform where their own citizen projects can be started. In addition, there are two other studies that make their source code publicly available [4, 18]. In summary, only 5 of 12 software-systems are publicly available. The majority of the studies (10 of 12) allow participation via mobile apps or web applications. Only two systems are desktop software.

Regarding citizen participation in the studies (research question 3), it can be stated that the identified projects allow different participation possibilities, from the creation of one's own research data to the active evaluation and discussion of the data. However, this publication did not investigated how many citizens used the software and whether research questions were able to be answered using those systems. For the SelEe project, the existing systems must be checked for their applicability. These selection process will take place together with the participating citizens. They will define requirements to those systems and then it is checked whether the systems fit these requirements. In a next step, 
we will conduct a focus group in which the systems are presented and the participants vote on which system will be used in the project.

Concerning research question 4 , the studies identified in this review focus on the evaluation of their research questions in their research area, but did not investigate the acceptance by the user or usability of their tools. This may have an impact on the research results created by citizens and should be investigated in further studies. However, there are studies outside the medical environment available, which make clear, that the inclusion of the user in an early stage of the project is necessary to increase success and acceptance [22]. Therefore, a user-centred design approach could be a possibility to allow the participation of citizen in the design of the software and not just in the research process $[23,24]$. Hence, we derive this user-centricity as an essential criterion in the implementation for our SelEe-project.

\subsection{Limitations}

This work provides a broad overview of 12 software-systems to support the citizen science process in the medical area. In other science domains, there could be further suitable systems. Furthermore, not every system could be explained in detail. For example, no further technical details were omitted. Nevertheless, future studies can use this as a basis to carry out more detailed investigations, e.g. if data could be exported into statistic software-systems. However, the data collection of this review was limited to PubMed and not published literature was not covered. Additionally, the study selection and data charting were only performed by one author, but results in any phase of the study were approved by all authors. Furthermore, as mentioned above, we could not identify any evidence of RDs projects in citizen science in this review. Due to the fact that 5 articles were excluded because of missing full-text, this could have an impact on the completeness of this review. In addition, we do not address the risk of bias. However, the use of a high methodological standard with PRISMA-ScR could minimize a possible bias across the study.

\section{Conclusions}

In this review, we summarized the literature of citizen science projects in human medicine between 2011 and 2021. Our study provides insights of how citizens were involved by using software-based systems and we identified software-systems in each citizen science project to manage projects and involve citizens.

\section{Declarations}

Conflict of Interest: The authors declare that there is no conflict of interest.

Acknowledgement: This work was supported by the German Federal Ministry of Education and Research (BMBF - FKZ 01BF2112A, 01BF2112B).

Author contributions: JAS and MN designed the review, formulated research questions and performed study selection as well as data analysis. The results of this scoping review 
were summarized and reported by JAS and reviewed by MN. JS, HS and MS revised the article. The final manuscript was written by JAS and approved by all authors.

\section{References}

[1] scistarter - Science we can do together, What is Citizen Science?, (2021). https://scistarter.org/citizenscience (accessed July 29, 2021).

[2] Aristeidou M, Herodotou C, Online Citizen Science: A Systematic Review of Effects on Learning and Scientific Literacy, Citizen Science: Theory and Practice. 5 (2020), 11. doi: http://doi.org/10.5334/cstp.224

[3] Caputo B, Manica M, Filipponi F, Blangiardo M, Cobre P, Delucchi L et al., ZanzaMapp: A Scalable Citizen Science Tool to Monitor Perception of Mosquito Abundance and Nuisance in Italy and Beyond, Int. J. Environ. Res. Public. Health. 17 (2020). doi:10.3390/ijerph17217872.

[4] Ulahannan J.P, Narayanan N, Thalhath N, Prabhakaran P, Chaliyeduth S, Suresh S.P. et al., A citizen science initiative for open data and visualization of COVID-19 outbreak in Kerala, India, J. Am. Med. Inform. Assoc. JAMIA. 27 (2020), 1913-1920. doi:10.1093/jamia/ocaa203.

[5] Wiggings A, Wilbanks J, The Rise of Citizen Science in Health and Biomedical Research, Am J Bioeth, 19 (2019), 3-14. doi: 10.1080/15265161.2019.1619859

[6] Wald D.M., Longo J, Dobell A.R., Design principles for engaging and retaining virtual citizen scientists, Conserv. Biol. J. Soc. Conserv. Biol. 30 (2016), 562-570. doi:10.1111/cobi.12627.

[7] Bundesministerium für Bildung und Forschung (BMBF), Karliczek: "Wir wollen die Bürgerforschung in Deutschland nachhaltig im Wissenschaftssystem verankern", (2020). https://www.bmbf.de/de/karliczek-wir-wollen-die-buergerforschung-in-deutschland-nachhaltig-im13592.html (accessed March 17, 2021).

[8] Schaaf J, Sedlmayr M, Prokosch H, Storf H, Evaluation of a Clinical Decision Support System for Rare Diseases - a qualitative study. BMC Med Infor. Dec. Mak. 21 (65).

[9] M Neff, Schaaf J, Tegtbauer N, Schaefer J, Till M, T.O.F. Wagner, Graeßner H, Mundlos C, Storf H, se-atlas.de - Versorgungsatlas für Menschen mit Seltenen Erkrankungen, Internist (2021). doi: https://doi.org/10.1007/s00108-021-01085-y

[10] Ventola C.L., Mobile Devices and Apps for Healthcare Professionals: Uses and Benefits. P.T. 39(5), 356-364.

[11] Liberati A, Altman D, Tetzlaff J, Mulrow C, Gøtzsche P.C., Ioannidis J.P.A. et al., The PRISMA statement for reporting systematic reviews and meta-analyses of studies that evaluate health care interventions: explanation and elaboration, PLoS medicine. 6 (2009), e1000100. doi:10.1371/journal.pmed.1000100.

[12] Hartshorne J.K, de Leeuw J.R., Goodman N.D., Jennings M, O’Donnell T.J., A thousand studies for the price of one: Accelerating psychological science with Pushkin, Behav. Res. Methods. 51 (2019), 1782-1803. doi:10.3758/s13428-018-1155-z.

[13] Vicens J, Perelló J, Duch J, Citizen Social Lab: A digital platform for human behavior experimentation within a citizen science framework., PloS One. 13 (2018), e0207219. doi:10.1371/journal.pone.0207219.

[14] Wang Y, Kaplan N, Newman G, Scarpino R, CitSci.org: A New Model for Managing, Documenting, and Sharing Citizen Science Data., PLoS Biol. 13 (2015), e1002280. doi:10.1371/journal.pbio.1002280

[15] Klepac P, Kissler S, Gog J, Contagion! The BBC Four Pandemic - The model behind the documentary, Epidemics. 24 (2018), 49-59. doi:10.1016/j.epidem.2018.03.003.

[16] Candido Dos Reis F.J., Lynn S, Ali H.R., Eccles D, Hanby A, Provenzano E et al., Crowdsourcing the General Public for Large Scale Molecular Pathology Studies in Cancer, EBioMedicine. 2 (2015), 681689. doi:10.1016/j.ebiom.2015.05.009.

[17] Meakin J.R., Ames R.M., Jeynes J.C.G., Welsman J, Gundry M, Knapp K et al., The feasibility of using citizens to segment anatomy from medical images: Accuracy and motivation, PloS One. 14 (2019), e0222523. doi:10.1371/journal.pone.0222523.

[18] McGehee A.J., Bhattacharya S, Roche R., Bhattacharya D, PolyFold: An interactive visual simulator for distance-based protein folding, PloS One. 15 (2020), e0243331. doi:10.1371/journal.pone.0243331.

[19] Kawrykow A, Roumanis G, Kam A, Kwak D, Leung C, Wu C et al., Phylo: a citizen science approach for improving multiple sequence alignment, PloS One. 7 (2012), e31362. doi:10.1371/journal.pone.0031362. 
[20] Tuckett A.G., Freeman A., Hetherington S, Gardiner P.A., King A.C., Older Adults Using Our Voice Citizen Science to Create Change in Their Neighborhood Environment, Int. J. Environ. Res. Public. Health. 15 (2018). doi:10.3390/ijerph15122685.

[21] Sheats J.L., Winter S.J., Romero P.P, King A.C., FEAST: Empowering Community Residents to Use Technology to Assess and Advocate for Healthy Food Environments, J. Urban Health Bull. N. Y. Acad. Med. 94 (2017), 180-189. doi:10.1007/s11524-017-0141-6.

[22] Kushniruk A.W., Patel V.L., Cognitive and usability engineering methods for the evaluation of clinical information systems, J Biomed Inform. 37 (2004), 56-76.

[23] H.O'Keefee W, Walls D. Usability Testing Design And Experience Design in Citizen Science: A Case Study, SIGDOC '20: Proceedings of the 38th ACM International Conference on Design of Communication. 33 (2020), 1-8. https://doi.org/10.1145/3380851.3416768

[24] Skarlatidoum A, Ponti M, Sprinks J, Nold C, Haklay M, Kanjo E, User experience of digital technologies in citizen science, Journal of Science Communication, 18 (2019), 1-8. doi $10.22323 / 2.18010501$. 